\title{
Opintojen henkilökohtaistaminen oppisopimuskoulutuksessa
}

ANNE SIVONEN

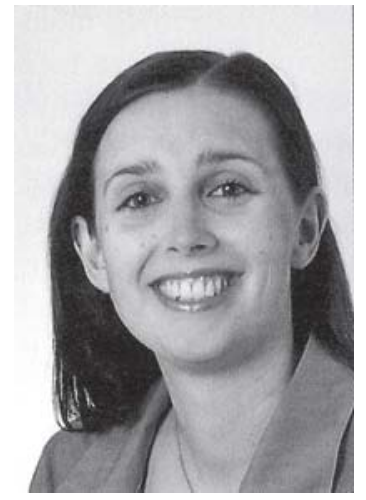

Aikuisopiskelun henkilökohtaistaminen on ollut vilkkaan keskustelun kohteena oppilaitosmaailmassa oikeastaan koko 2000-luvun alun ajan. Vuoden 2006 alusta voimaan tullut uudistettu laki ammatillisesta aikuiskoulutuksesta säätelee omalta osaltaan henkilökohtaistamiseen liittyvää toimintaa. Käsite on monitahoinen ja näyttäytyy eri osapuolille eri tavoin. Kuvaan opiskelijan ja ammatillisen ohjauksen näkökulmasta sitä, millaisia elementtejä aikuisoppisopimusopiskelijan henkilökohtaistamisprosessiin kuuluu ja millaista pedagogista tukea hänelle prosessin aikana tarjotaan.
$\mathrm{O}_{\mathrm{p}}$ ppisopimus perustuu työsuhteeseen ja työssä tapahtuvaa oppimiseen, jota tukee oppilaitoksesta saatava tietopuolinen opetus. Oppimisprosessi etenee oppilaitoksen kanssa yhteistyössä tehtävien henkilökohtaisten oppimis- ja näyttösuunnitelmien mukaan, joissa pyritään ottamaan huomioon sekä työnpaikan että opiskelijan tarpeet ja edellytykset. Oppimis- ja näyttösuunnitelman runkona ovat opiskeltavan tutkinnon perusteissa mainitut ammattitaitovaatimukset ja niihin liittyvät arviointikriteerit.

Vantaan ammattiopiston henkilökohtaistamistyöryhmä kokosi yhteen opintojen henkilökohtaistamiseen vaikuttavia tekijöitä ja sitä viitekehystä, jonka puitteissa opintoja oppisopimuskoulutuksessa henkilökohtaistetaan. Tulos on koottu kuvioksi, joka on nähtävänä netissä (ks. sivu 222). Siitä käy ilmi, miten henkilökohtaistaminen rakentuu yhteistyössä eri osapuolten välillä. Oman artikkelinsa ansaitsisivat koulutusorganisaatioiden toimintaan liittyvät käytänteet, joita kuvataan katkoviivan yläpuolella olevassa kentässä. Keskityn kuitenkin tässä artikkelissa käsitteen avaamiseen opiskelijan ja ammatillisen ohjauksen näkökulmasta.

Aikuisopiskelun henkilökohtaistamisella tarkoitetaan opiskelijan olemassa olevan osaamisen tunnistamista ja tunnustamista eli opiskelijan kanssa yhteistyössä tehtävää opintojen suunnittelua ja toteuttamista. Henkilökohtaistamisen tavoitteena on sovittaa ja soveltaa suoritettavan tutkinnon perusteet opiskelijan ja hänen työpaikkansa tarpeisiin. Nämä elementit näkyvät kuviossa katkoviivan alapuolella, asiakkaan kentässä.

Entä miten henkilökohtaistaminen tapahtuu? Henkilökohtaistaminen on ennen kaikkea inhimillistä kohtaamista, joka oppisopimuksen kohdalla tarkoittaa henkilökohtaisia ohjauskeskusteluja kouluttajan ja opiskelijan välillä, ohjauksellisia työpaikkakäyntejä ja riittävää lähiopetusta oppilaitoksessa. Käytännössä tämä merkitsee sitä, että kouluttajille on resurssoitava aikaa henkilökohtaistamiseen ja sen ohjaukseen. Koulutuksen järjestäjän ja oppijan välisen rajapinnan ylittämiseen tarvitaan runsaasti yhteydenpitoa ja oppilaitoksesta ja työpaikalta saatavaa henkilökohtaista ohjausta. Henkilökohtaistaminen vaatii siten laadukasta oppimisprosessin ohjausta, jossa apuna voidaan käyttää erilaisia pedagogisia välineitä.

\section{Henkilökohtaistuminen tuo merkityksen}

Omaehtoisesti opiskelemaan lähtevät aikuiset tekevät harvoin suurisuuntaisia ponnistuksia opintojen ja ammatillisuuden edistämiseksi, mikäli eivät koe opiskelua henkilökohtaisesti merkitykselliseksi. Tämän vuoksi oppisopimuskoulutuksessa - ja aikuiskoulutuksessa yleensäkin - pyritään 
opintojen henkilökohtaistamiseen. Henkilökohtaistamisessa tärkeiksi nousevat arkielämän kysymykset oppimisen esteistä ja edistäjistä, työn, perheen, opiskelun ja vapaa-ajan yhteensovittamisesta sekä omasta motivaatiosta. Aikuisopiskelijan olisi hyvä vastata esimerkiksi kysymyksiin "millainen minä olen oppijana", "mitä minä todella haluan elämässäni saavuttaa" ja "kuka minä olen tässä ammatissa”. Ilman kokonaisuuden ymmärtämistä ja henkilökohtaisen merkityksen löytämistä opiskelu saattaa jäädä pinnalliseksi eikä tuota ammatinhallinnankaan kannalta niin suuria onnistumisia kuin hyvin suunniteltu ja sisäistetty oppimisprosessi.

Henkilökohtaistamista voidaan kuvata pedagogiseksi pyrkimykseksi vastata ammattitaidon kehittämisen haasteisiin. Henkilökohtaistaminen tapahtuu ohjausprosessissa, jossa opiskelijan opiskelulle asettamia tavoitteita, kokemuksia ja merkityksiä yhdistetään työelämän vaatimuksiin ja kyseessä olevan tutkinnon perusteisiin. Pelkistetysti voidaan puhua opiskelijan oman äänen kuulemisesta oppimisprosessissa. Tavoitteena on huomioida opiskelija yksilönä, joka paikantaa opiskelua omassa elämäntilanteessaan ja suhteuttaa sen muun muassa uratavoitteisiin, työssä jaksamiseen, työelämän tarpeisiin ja arkielämän organisointiin. Opiskelijan henkilökohtaisten merkitysten huomioiminen lisää hallinnan tunnetta opiskelussa ja parantaa paitsi ammatillista osaamista, myös työssä jaksamista. (Harju 2005.) Henkilökohtaistaminen on merkityksen ja kontekstin hakemista omalle oppimiselle ja se kuuluu kiinteästi aitoon sisältäpäin ohjautuvaan ammatillisuuteen. Oivallusten, uuden tiedon ja soveltamisen kautta opinnot lähtevät henkilökohtaistumaan eli opiskelija löytää henkilökohtaisesti ja inhimillisesti merkittäviä perusteita toiminnalleen.

Vaikka henkilökohtaistaminen sanana viittaa yksityiseen ja yksilölliseen, sen toteuttamisessa tulee huomioida kaikki oppisopimusverkoston tekijät. Sankarillisten yksilösuoritusten sijasta henkilökohtaistaminen tulee nähdä toimintajärjestelmänä, jossa mukana on monia asiantuntijoita, muun muassa opiskelija itse.

Täydellinen opiskelijalähtöisyys ei tutkintotavoitteisessa koulutuksessa ole mahdollista, sillä oppilaitos on tiukasti sidoksissa tutkinnon perusteisiin. Viimeistään näytöissä saatetaan kohdata ongelmia, jos ammattitaitovaatimuksia on liiaksi räätälöity opiskelijan toiveiden mukaan. Vahvassa roolissa ovat myös työnantajan tarpeet muun muassa sen vuoksi, että hän on tehnyt taloudellisia satsauksia oppisopimusopiskelijan eteen ja asettanut yrityksen kannalta tärkeitä osaamisen nostamiseen liittyviä tavoitteita. Näin ollen voi sanoa, että tutkinnon perusteet ja työelämän vaatimukset näyttelevät vähintään yhtä suurta roolia henkilökohtaistamisessa kuin opiskelijan lähtökohdatkin. Näyttääkin siltä, että täysin aitoon ja puhtaasti henkilökohtaistettuun koulutukseen on näyttötutkintojärjestelmän puitteissa vaikea päästä, koska järjestelmän tavoite on myös tuottaa samantasoista ja -sisältöistä osaamista suorituspaikasta riippumatta. Näin ollen opiskelijan ja työnantajan on hyvä tutustua tutkinnon perusteisiin jo koulutuksen suunnitteluvaiheessa ja hyväksyä se tosiseikka, että räätälöintiä voidaan tehdä nimenomaan näissä puitteissa.

\section{Ammatillisen ohjauksen haasteellisuus}

Uuden lain mukainen henkilökohtaistaminen on melko uusi toimintatapa monelle koulutuksen järjestäjälle. Retoriikan ja käytäntöjen välistä suhdetta kannattaa tarkastella kriittisesti siten, että pystytään erottamaan "henkilökohtaistamispuhe" konkreettisista opiskelijaa hyödyntävistä toiminnoista. Tähän kuiluun törmään jatkuvasti koulutustarkastajan tehtävässäni. Koulutuksen ostovaiheessa oppilaitokset esittävät monitahoisia henkilökohtaistamisprosesseja, mutta puolen vuoden koulutuksen jälkeen saatan kuulla opiskelijalta, että yhtään henkilökohtaista ohjauskeskustelua ei ole käyty tai suunnitelmaa tehty. Tällöin myöskään ajatus inhimillisestä ja ammatillisesta kohtaamisesta henkilökohtaistamisprosssissa ei ole toteutunut. Ilman dialogia ja reflektointia täytetyt oppimissuunnitelmat jäävät usein pinnallisiksi eivätkä nivelly opiskelijan omaan työyhteisöön tarkoituksenmukaisella tavalla. Niin sanotut yksilölliset ratkaisut kuten kurssien valitseminen kurssitarjottimelta eivät vielä tarkoita henkilökohtaistamista. Henkilökohtaistaminen fokusoi ensisijaisesti oppijoiden oppimisprosessien ja henkilökohtaisen ammatillisen kehittymisen varmistamiseen, ei niinkään teknisten oppisisältöjen valintaan (Pasanen 2000).

Ammatillisen kasvun ja henkilökohtaistumisen ohjaaminen on hyvin vaativaa ja herättää pohtimaan, löytyykö aikuiskouluttajilta tämän 
tyyppistä osaamista ja resursseja ohjaustilanteisiin? Monet aikuiskouluttajat kokevat epävarmuutta uudenlaisten roolipaineiden edessä. Merkitseekö henkilökohtaistaminen esimerkiksi jonkinlaisen terapeutin roolin omaksumista? Mikä on "puhdasta" tiedonjakamista, milloin on paikallaan neuvon antaminen, miten ohjaus eroaa neuvonnasta? Yksiselitteisiä tai mustavalkoisia vastauksia ei ole. Melko monet ohjaustilanteen vaatimukset tuntuvat palautuvan inhimillisen ammattitaidon käsitteeseen ja siihen liittyviin tunneelementteihin. Tämä puolestaan johdattaa miettimään, kuinka suuri osa inhimillisestä ammattitaidosta on synnynnäistä ja paljonko sitä pystyy kehittämään tietoisesti?

Ihanainen (2006) kirjoittaa inhimillisen ammattitaidon merkityksestä osuvasti todetessaan, että työn ja ammatin toteuttamisen ja harjoittamisen rinnalla voidaan puhua siitä, mitä ihminen ollessaan ihminen antaa ja tuo työhön ja ammattiin. Inhimilliset kvalifikaatiot tekevät inhimillisen ammattitaidon, joka puolestaan juurtuu tunteisiin. Ne ovat ihmisyyden keskiössä ja tekevät ajatukset ja toiminnan henkilökohtaiseksi. Ilman tunnesidosta, aitoa liittymistä, on vain koskettamattomia ja toistettuja ajatuksia ja tekoja. Inhimillinen ammattitaito voidaan jäsentää tunnetietoisuudeksi, tunneosaamiseksi, tunnevastuullisuudeksi ja moraaliseksi harkinnaksi ja toiminnaksi. (mt.) Vaikuttaisi siis siltä, että ilman inhimillistä ammattitaitoa on vaikea löytää aitoa ja merkityksellistä ohjaussuhdetta.

\section{Henkilökohtaistamisen pedagogisia välineitä}

Vaikka inhimillinen ammattitaito ja vuorovaikutusosaaminen ovat ehdottoman tärkeitä henkilökohtaistamisessa, löytyy oppisopimuksesta toki myös rakenteita ja pedagogisia välineitä henkilökohtaistamisen avuksi. Oppisopimuskoulutuksen tietopuolinen opetus alkaa useimmiten osaamiskartoituksella, jossa tunnistetaan ja tunnustetaan opiskelijan aikaisempi osaaminen. Kartoitukset vaihtelevat tutkinnoittain ja oppilaitoksittain ja niissä voidaan kartoittaa paitsi substanssin hallintaa, myös opiskelu- ja vuorovaikutustaitoja. Osaamiskartoitusten pohjalta opiskelija, työpaikkaohjaaja ja oppilaitoksen kouluttaja laativat yhteistyössä ensimmäisen version henkilökohtaisesta opiskelusuunnitelmasta eli hopsista. Hopsissa määritellään suoritettava tutkinto, opetus- tai näyttösuun- nitelman peruste ja tutkinnon laajuus. Keskeisenä sisältönä ovat työssä oppimisen suunnitelma ja teoriaopintojen sijoittuminen oppisopimusajalle sekä henkilökohtainen näyttösuunnitelma (hensu). Näyttösuunnitelmassa kuvataan näyttöympäristö, näyttöjen ajankohdat sekä näytön vastaanottajat.

Henkilökohtaisten suunnitelmien laatiminen ja päivittäminen edellyttävät paitsi opiskelijan osaamisen, myös hänen kontekstinsa ymmärtämistä. Oppisopimuskoulutukseen hyvin soveltuvan kontekstuaalisen oppimisen oppimiskäsityksen mukaan oppimiseen ja ammatillisuuteen vaikuttavat paitsi oppijan oma toiminta ja kokemus, myös kokemusta muokkaava toimintaympäristö, tilanteet ja taustat (Uola 2002). Koska konteksti ja siinä toimiva oppija ovat jatkuvasti muutoksessa, tulisi henkilökohtaisia suunnitelmia päivittää koko opiskeluprosessin ajan.

Pasasen (2000) mukaan henkilökohtaisissa oppimissuunnitelmissa ohjaudutaan helposti kapeisiin ja teknisiin kvalifikaatiomäärityksiin, jotka määritellään muuttumattomiksi jo koulutuksen alussa. Tätä mallia kutsutaan yksillöllistämisen tai teknistämisen malliksi. Mallissa aikuisopiskelija etenee alussa määriteltyä reittiä pitkin koulutuksen loppuun asti. Tämä on ongelmallista sikäli, että opiskelijan on usein vaikea arvioida itseään 'oikein' heti koulutuksen alussa, kun esimerkiksi käsitteet ovat vieraita. Lisäksi opiskelijoiden itsearviointitaidot vaihtelevat runsaasti. Teknisessä mallissa yksilöllisyyttä ei hahmoteta laadullisesti, vaan usein lopputuloksena on samanlainen oppimispolku koko opiskeluryhmälle. Henkilökohtaistaminen voidaan nähdä yksilöllistämisen seuravana askeleena. Sen mukaan kulttuuriset merkitykset ja asioiden henkilökohtainen mieli voivat syntyä vain suhteessa muiden kanssa. Tämä näkökulma puoltaa laajaa ja avointa hopsia, joka perustuu alun kartoituksen jälkeen suunnitelman päivittämiseen, ohjauskeskusteluihin ja muuhun henkilökohtaiseen vuorovaikutukseen.

Hops ja hensu ovat henkilökohtaistamisen perustyökaluja ja niiden olemassaoloa vaaditaan oppisopimuksessa myös lakisääteisesti. Uudistetussa laissa ja Opetushallituksen määräyksissä henkilökohtaistamissuunnitelma jaetaan hakeutumisen vaiheeseen sekä näyttötutkinnon suorittamisen ja tarvittavan ammattitaidon hankkimisen vaiheisiin. Suunnitelmien työstämiseen liittyvät useimmiten henkilökohtaiset ohjauskeskustelut ja 
ohjaukselliset työpaikkakäynnit, joiden aikana kouluttaja perehtyy oppisopimusopiskelijan työn kontekstiin ja henkilökohtaisiin ammatillisen kasvun mahdollisuuksiin. Suunnitelmien työstämisessä voidaan käyttää apuna ryhmä- ja vertaisohjausta. Vantaan oppisopimuspalveluiden opiskelijoille suositellaan lisäksi erilaisia itsearviointimenetelmiä kuten oppimispäiväkirjan pitämistä, kirjoitelmaa omista työelämätaidoista sekä osaan.fi -portaalin käyttöä verkossa (www.osaan.fi). Näiden välineiden käyttö on ohjeistettu opiskelijoille jaettavissa oppisopimuskansiossa ja tehtävät pyritään purkamaan yhdessä vastuukouluttajan kanssa ensimmäisessä ohjauskeskustelussa.

Aikuisten oppisopimukseen liittyviä henkilökohtaistamis- ja arviointimenetelmiä on kehitetty osana Optio -aikuisten oppisopimusprojektia, jossa koulutettiin 180 aikuista oppisopimuksella perus-, ammatti- tai erikoisammattitutkintoon vuosina 2002-2005 (Sivonen \& Jussila 2005). Nykyisissä oppisopimuksissamme itsearviointia tukee puolivuosittain toteutettava oppisopimuksen seuranta ja arviointi, jossa pyydetään työpaikkaohjaajaa ja opiskelijaa yhdessä arvioimaan opiskelijan työssä oppimisen, tietopuolisen opetuksen ja ammattitaidon kehittymisen etenemistä.

Osaamiskartoitukset, henkilökohtaiset suunnitelmat ja itsearvioinnit keskittyvät lähinnä opiskelijan osaamisen arviointiin. Osaamisen tunnistamisen lisäksi henkilökohtaistamiseen tulisi kuitenkin kuulua myös opiskelijan elämäntilanteen huomiointi. Tätä taustaa vasten eräänä henkilökohtaistamisen välineenä voidaan pitää oppisopimusopiskelijoiden käyttöön suunniteltua elämänkarttaa. Elämänkartta on sosiodynaamiseen ohjaukseen perustuva elämänorganisoinnin työkalu, jonka avulla aikuisopiskelija määrittelee omaan oppimiseen ja ammatilliseen kehittymiseensä vaikuttavat tekijät. Elämänkartan avulla opiskelijat pyrkivät hahmottamaan sen hetkisen elämänkokonaisuutensa osa-alueet työn, perheen, opiskelun ja vapaa-ajan. Samalla elämänkartta toimi ajankäytön ja opintojen suunnittelun välineenä. (Sivonen \& Jussila 2005; Sivonen 2006.)

Erilaisten pedagogisten välineiden ja ohjaustapojen käyttö jäsentää sekä opiskelijan oppimisprosessia että kouluttajan työtä. Välineiden onnistunut käyttö palautuu hyvää ohjaussuhteeseen, jonka perustana on kouluttajan inhimillinen ammattitaito ja riittävät henkilökohtaiset kontaktit ohjaajan ja ohjattavan välillä. Jo vakiintuneen määritelmän mukaan ohjaus on aikaa, huomiota ja kunnioitusta (esim. Onnismaa 2006). Ilman näitä elementtejä ei synny myöskään henkilökohtaistunutta ammatillista oppimisprosessia.

Ohjauksen lisäksi tärkeää roolia näyttelevät tietopuolisen opetuksen lähipäivät, jotka omalta osaltaan mahdollistavat kokemusten ja näkemysten vaihdon ryhmässä sekä päivittävät teoreettista osaamista. Ryhmässä opiskelijat voivat muodostaa opittaville asioille jaettuja merkityksiä ja saada niille henkilökohtaista mieltä. Lähipäivien tarjoama keskustelufoorumi onkin siinä määrin tärkeä, että opiskelijat melko harvoin käyttävät mahdollisuuttaan "hyväksilukea” teoriapäiviä, joita muutenkin on oppisopimuksessa erittäin vähän. Tämä suuntaus on osin vastakkainen koulutuspoliittisten linjausten kanssa.

\section{Henkilökohtaistaminen yksilön ja kou- lutuspolitiikan silmin}

Henkilökohtaistamisen mieli ja tavoitteet näyttäytyvät eri tavoin yksilöllisestä ja pedagogisesta näkökulmasta kuin koulutuspoliittisesti katsottuna. Opetushallituksen taholta on korostettu, että näyttötutkintojärjestelmä on nimenomaan ammattitaidon osoittamisen ja tutkinnon suorittamisen järjestelmä, ei koulutusjärjestelmä. Virallisesti nimitystä opiskelija ei tulisi enää käyttää, vaan oikea termi on tutkinnon suorittaja. Henkilökohtaistamissuunnitelmassa ensimmäisen ja toisen vaiheen idea on, että tutkinnon suorittajan osaaminen kartoitetaan ja hänelle tehdään suunnitelma näyttöjen suorittamiseksi. Vasta kolmannessa vaiheessa siirrytään sisällölliseen oppimisprosessiin eli hankitaan tarvittava ammattitaito, jos sitä ei kartoitusten perusteella ole ennestään. (www.finlex.fi/fi/laki/ ajantasa/1998/19980631 ja www.oph.fi/kehittämishankkeet/AiHe-projekti.)

Onko rivien välistä on luettavissa, että mahdollisimman monen toivotaan menevän suoraan näyttöön ja suorittavan tutkintonsa nopeassa tahdissa (ja myös kaunistavan tilastoja suoritetuista ammattitutkinnoista)? Käytännössä varsinkin oppisopimuksen piirissä lähes kaikki opiskelijat kuitenkin tarvitsevat ja haluavat tutkintoon valmistavaa koulutusta, sillä sen sisällöllä ja ammattitaidon kehittymisellä on heille suurempi merkitys kuin itse tutkinnolla. 


\section{Lähteet}

Harju, A. (2005). Henkilökohtaistaminen tukee ammatillista kasvua. AiHe-projektin www-sivuille laadittu artikkeli. www.oph.fi/kehittämishankkeet/AiHe-projekti. 29.12.2005.

Ihanainen, P. (2006). Henkilökohtaistamisen ydintä on inhimillinen ammattitaito. AiHe-projektin www-sivuille laadittu artikkeli. www.oph.fi/kehittämishankkeet/AiHe-projekti. 28.3.2006.

Onnismaa, J. (2007). Ohjaus ja neuvontatyö. Aikaa, huomiota ja kunnioitusta. Helsinki: Gaudeamus.

Pasanen, H. (2000). Oppimisen ohjauksen tarve ammatillisessa aikuiskoulutuksessa. Teoksessa Onnismaa, J., Pasanen, H. ja Spangar, T. (toim.) Ohjaus ammattina ja tieteenalana 2. Jyväskylä: PS-kustannus.

Sivonen, A. \& Jussila, K. (2005). Aikuisopiskelijan orientoituminen opiskeluun ja opintojen henkilökohtaistaminen - opinnoista merkityksellinen osa elämää. Teoksessa Seppälä, T. (toim.) Aikuisten oppisopimus - osaamista ja kilpailukykyä työpaikoille. Helsinki: Yliopistopaino.

Sivonen, A. (2006). Elämänkartta ammatillisen kasvun tukena - kokemuksia aikuisten oppisopimuskoulutuksesta. Teoksessa Eteläpelto, A. \& Onnismaa, J. (toim.) Ammatillisuus ja ammatillinen kasvu. Aikuiskasvatuksen 46. vuosikirja. Kansanvalistusseura ja Aikuiskasvatuksen Tutkimusseura. Helsinki: Kansanvalistusseura.

Uola, A. (2002). Tiedon muuntuminen ammatilliseksi osaamiseksi oppisopimuskoulutuksessa. Tampereen yliopiston kasvatustieteiden laitoksen julkaisuja. Sarja A, nro 61.

www.oph.fi/kehittämishankkeet/AiHe-projekti. 27.4.2006.

www.finlex.fi/fi/laki/ajantasa/1998/19980631

www.osaan.fi 27.4.2006

Kuvio Henkilökohtaistamisprosessi ja sen eteneminen: www.kansanvalistusseura.fi > Lehdet > Lehtien irtonumerot ja aikaisemmat numerot (myös etusivulta Tuoreimmat julkaisut > Aikuiskasvatus 2007 nro 3, missä Anne Sivosen artikkelin nimestä aktivoituu kuvio. 